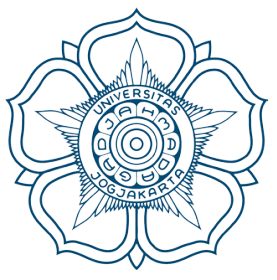

Title

: THE EXISTENCE OF THE LESBIAN, GAY, BISEXUAL AND TRANSGENDER (LGBT) COMMUNITY IN THE PERSPECTIVE OF A STATE BASED ON PANCASILA

Author : I Nyoman Sujana, Komang Arini Setyawati, and Ni Made Puspasutari Ujanti

MIMBAR HUKUM

DOI $\quad:$ http://doi.org/10.22146/jmh.28655

Publisher : : Faculty of Law Universitas Gadjah Mada

URL : jurnal.ugm.ac.id/jmh

E Issn : :2443-0994

P Issn : :0852-100x 


\title{
THE EXISTENCE OF THE LESBIAN, GAY, BISEXUAL AND TRANSGENDER (LGBT) COMMUNITY IN THE PERSPECTIVE OF A STATE BASED ON PANCASILA*
}

\author{
I Nyoman Sujana, ${ }^{* *}$, Komang Arini Setyawati, ${ }^{* * *}$ and Ni Made Puspasutari Ujanti ${ }^{* * * *}$ \\ Civil Law Department, Faculty of Law, Universitas Warmadewa Denpasar \\ Jl. Terompong No. 24 Tanjung Bungkak, Denpasar, Bali, 80235
}

\begin{abstract}
The existence of a lesbian, gay, bisexual and transgender community is a necessity. This study aims to understand Pancasila's view of the existence of Lesbian, Gay, Bisexual, and Transgender (LBGT) communities in Indonesia against the noble values contained in Pancasila and what alternative solutions can be offered in order to prevent and mitigate the impact of LBGT communities in society. Based on the research that has been done using empirical law research method, it can be seen that the existence of this $L G B T$ community does not conflict with the value of noble values of Pancasila.
\end{abstract}

Keywords: human rights, LGBT, pancasila.

\section{Intisari}

Keberadaan komunitas Lesbian, Gay, Biseksual, dan Transgender (LGBT) di Indonesia masih dilematis. Sebagian masyarakat memandang komunitas LGBT melanggar norma hukum, agama maupun kesusilaan. Namun, di lain pihak ada sebagian masyarakat yang menganggap komunitas LGBT adalah bagian yang tak terpisahkan dari masyarakat pada umumnya. Penelitian ini bertujuan memahami pandangan Pancasila terhadap keberadaan komunitas LGBT di Indonesia. Metode penelitian menggunakan metode hukum empiris. Hasil penelitian menunjukan bahwa keberadaan komunitas LGBT tidak bertentangan dengan nilai-nilai luhur Pancasila.

Kata Kunci: hak asasi manusia, LGBT, pancasila.

\section{Pokok Muatan}

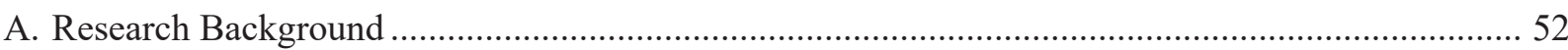

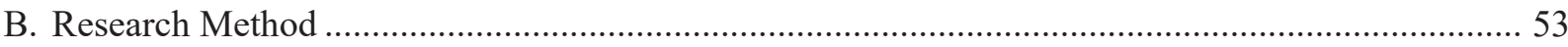

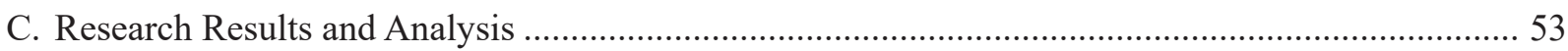

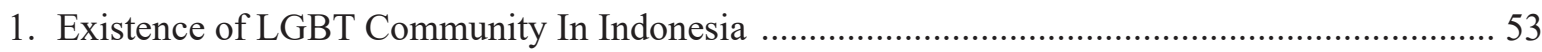

2. LGBT Community in A State Based on Pancasila ....................................................................... 54

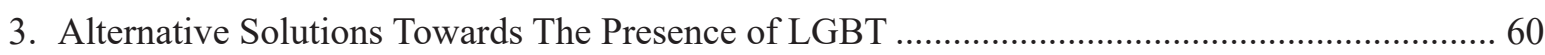

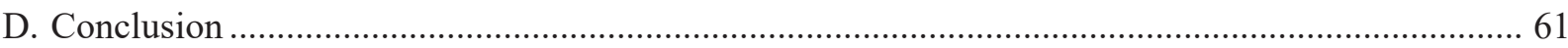

\footnotetext{
This research is funded by the Ministry of Research, Technology and Higher Studies' Fundamental Research competitive grant program with the deed of assignment agreement No. 1130/K8/KM/2017.

** Correspondence address: nyomansujanaa2015@gmail.com.

*** Correspondence address: arinistyawati@gmail.com.

***** Correspondence address: puspa.niwapong@gmail.com.
} 


\section{A. Research Background}

The existence of a community for Lesbian, Gay, Bisexual and Transgender hereinafter referred to as LGBT is inevitable. There are members of the public that views this community to have created social problems, and even have the tendency to be regarded as spreading ideologies violating the norms of religion and the norms of morality. Those who accept the LGBT community are of a different view, that no one has the desire to behave like an LGBT, nor aspire to be an LGBT. All of that is by the grace of the Almighty, which flows just like that. Prohibiting the creative space of LGBTs is a violation of Human Rights which are not accommodated within Pancasila.

Those who support the LGBT community uses Human Rights as a shield. Meanwhile, those who are against the community are of different views. They have the tendency to be 'hard' by stating that Allah SWT/God Almighty strictly prohibits His people from joining into the category of people who likes those of the same sex. On the other hand, the LGBTs are of the opinion that their existence should not be attributed to holyscriptures, and that they were born into the world based on the will of Allah SWT.

Law No. 1 of 1974 regarding Marriage, hereinafter referred to as Marriage Law especially in Article 1 paragraph (1) imitatively and strictly stipulates that:

Marriage is a physical and spiritual bond between a man and a woman as husband and wife with the purpose of establishing a family (household) which is happy and lasting founded on the belief in God Almighty.

Based on the provisions of Article 1 paragraph (1) of Marriage Law stated above, it can be inferred that in Indonesia only marriage between a man as the husband and a woman as the wife is accepted. The provisions of the aforementioned article, does not regulate same-sex marriage. Therefore, the LGBT Community is in no way regulated under Law No. 1 of 1974. Hence, the LGBT community is accused of behaving in a way deviating from and violating the law.

On the other hand, the actors of LGBT regard themselves to have the same rights as other citizens in general. There are two grounds used as reference. First, as a State based on the rule of law each citizen of the State has equal rights and treatment before the law. Second, they seek refuge behind Human Rights by referring to the ideology of several states in the United States of America that have legalized samesex marriage. This phenomena surely is regarded as a breath of fresh air for the LGBT community so that the government will amend the Marriage Law or that there will appear a party willing to submit a judicial review to the Constitutional Court so that provisions where marriage may only be conducted by a man as the husband and a woman as the wife is changed.

This research aims to identify all the problems related to the existence of the LGBT community in the society especially in the Republic of Indonesia as a State based on Pancasila. Further, to attempt in seeking an alternative solution to solve the problems. The research problems that have been formulated are: (1) Is the existence of an LGBT community in Indonesia in contravention with the noble values contained in Pancasila as the Fundamental Principle of the State?; (2) How does the legal aspect arise from the development of the LGBT phenomena in the society?; and (3) What alternative solution can be offered in the effort of preventing and reducing the negative impact of the existence of the LGBT community?

Discussions on the LGBT community is a very complex matter, hence a comprehensive approach and solution is needed. It is of course not easy, but it needs to be done as libeling, insulting or ostracizing the LGBT community is not a good solution. As based on reasons of humanity, they also are legitimate citizens of the Republic of Indonesia. It seems to not be very wise or prudent to comment on the LGBT discussion with references and basis solely on divide revelation. The history of human civilization notes the existence of such LGBT 
community throughout the ages.

\section{B. Research Method}

This research on LGBT is based on the model of empirical legal research by using the approach of direct surveying on the field. The researchers made observations, direct interviews with members of the LGBT community, experts, informants who have been pre-determined and used as research samples. One of the characteristics of an empirical legal research is that researchers go directly to the location of the research to conduct observations in a relatively long time period and recording the phenomenon of societal behavior which turned into research sample. ${ }^{1}$

\section{Research Results and Analysis}

\section{Existence of LGBT Community In Indonesia}

Before discussing further regarding the legal issues which are the focus of the study in this research, in order to avoid any confusion of understanding, it is deemed necessary to first limit the meaning of some terms to be used in this article. These terms are: existence, lesbian, gay, bisexual, transgender (LGBT) community, and State based on Pancasila. All of these terms are embedded in the substance of the topic that is the subject of this article.

Existence is a word derived from Latin which is existere which has the meaning of: to appear, to become, to arise and to be. This then spawns four new explanations of existence, among others: existence is what has become; existence is what is had; existence is everything that has been experienced with the emphasis that something exists. Existence is perfection. In Kamus Besar Bahasa Indonesia (KBBI), existence is defined as presence. $^{2}$

Community, substantively is a social group having similar environmental habitat and interests within the scope of beliefs or other common scopes. In biological science, the definition of a community is a collection of several populations that congregate and live together in a particular region/environment. LGBT is the abbreviation of the term Lesbian, Gay, Bisexual and Transgender. The definitions of the terms mentioned above are: ${ }^{3}$

1. Lesbian is a term used for women who direct their sexual orientation to fellow women. The term also refers to women who love other women whether physically, sexually, emotionally, or spiritually. This term may be used as a noun if it refers to a woman who likes the same sex, or as an adjective if it carries the meaning of characterization of object or activity which is tied to same-sex relationship between women.

2. Gay is a term commonly used to refer to people of homosexual orientation or those displaying the nature of homosexuality. This term was originally used to express feelings of "free/unrestrained", "happy" or "bright" and "flashy". This term has then begun to be used to refer to homosexuality.

3. Bisexual is a term commonly used to refer to romantic attraction, sexual attraction or sexual orientation in both men and women. This term is generally used in the context of human interest in portraying romantic or sexual feelings to both men and women alike.

4. Transgender is a term commonly used for a person who has a gender identity or gender expression that is different from his or her designated sex at birth. Transgender people are also sometimes referred to as transsexuals if they seek medical help to transition from one sex to another. Transgender is also a common term, in addition to referring to a person whose gender identity is opposing to their designated sex (trans-male and trans-females). The term transgender can also include people who are not

\footnotetext{
Peter Mahmud Marzuki, 2008, Metode Penelitian Hukum, Gramedia, Jakarta, p.32. 
specifically masculine or feminine. The gender referred to in this study is unlike many people's assumptions that equate gender with sex, but the word gender referred to in this study is a socio-cultural attribute attached to a particular gender. In essence, sex is something given biologically, while gender is socially-formed. For example, in Indonesia human beings with vaginas are required to behave in a feminine manner, being a gentle person or wearing pink-clad clothes. The standards of masculinity and femininity in a certain place may differ from the standards elsewhere because of different cultural characteristics.

In a bid to study further regarding the presence of the LGBT community in Indonesia, hence the theoretical framework or theoretical basis that will be used to analyze the problems above is the Negara Hukum Theory. The term "Negara Hukum" used in this research is a translation of the term Rule of Law in English, or Rechtsstaat in German, or Etat de droit in French, which in general contains an identical definition, which is sovereignty or supremacy of law above the people and that the government is bound by law. ${ }^{4}$ This emphasis is important because there are other terms that can also be translated as "Negara Hukum" in the Indonesian language. The terms in question are the terms "Gesetzesstaat" and "Socialist Legality" (formerly commonly used by states under the communist regime) which puts emphasis on the understanding that regulations are binding regardless of the question of good-bad, just or unjust, as it was created by parties with the authority to create it. On the other hand the concept of the Rule of Law (Rechtsstaat or Etat de droit) implies a far more profound definition which is that everyone is bound by the law, including the government, not only because the law was created by those authorized to create and have them enacted, but the law itself must be kind and just. ${ }^{5}$ Hence the theory of rule of law is used as the theoretical framework or the theoretical basis of this research is the theory that discusses the notion of Negara Hukum within the meaning of Rule of Law (Rechtsstaat or Etat de droit) and not state laws dealing with the notion of Gesetzesstaat and Socialist Legality.

The choice to use the Rule of Law theory as the theoretical framework or basis for this research on LGBT community, besides the theory of legal protection and the theory of human rights is based on the fact that this LGBT community, factually are as part of the citizens of the State are constantly marginalized, therefore through this research, the researches aims to examine in depth how the existence of the LGBT community can actually be acknowledged equally as the treatments towards citizens born under normal conditions.

\section{LGBT Community in A State Based on Pancasila}

Substantively speaking, a State based on Pancasila here refers to a state which creates that encompasses protection of humans, that is, to protect humanity passively by preventing arbitrary acts, and actively by creating societal human conditions that enable the social process to proceed reasonably so that every human being equally has a broad and equal opportunity to develop in whole the full potential of their humanity.

Based on a study of the Philosophy of Pancasila, every citizen as legal subjects who advocates rights and obligations should be seen as they are. Through self-awareness, the essence of freedom, independence, health, purpose of life and honor as well as personal dignity, love, sincerity will develop optimally under the control of the noble values of Pancasila. ${ }^{6}$ The phenomenon of human identity is recognized by all the world's major religions and civilization of mankind

\footnotetext{
I Dewa Gede Palguna, 2013, Pengaduan Konstitusional (constitutional Complaint) Upaya Hukum Terhadap Pelanggaran Hak-Hak Konstitusional Warga Negara, Sinar Grafika, Jakarta, p.23. 
as a completely natural phenomenon like the topography of the land, where there are mountains, there are cliffs and there are also a lowlands. In the perspective of human rights should be seen as a whole. The mountains do not consider lowly of the rivers and seas. Conversely, the lowlands do not see the mountain as a natural phenomenon that must be eliminated. ${ }^{7}$

Similarly, the existence of the LGBT community. They are God's creations that deserve the same recognition as those born of normal orientation. It is fitting that the LGBT community should not be discriminated against in economic, legal or political terms. This is in line with the purpose of the formation of a government based on the law, so the law shall apply equally to them. Since the Proclamation of 17 August 1945 as a declaration of Indonesian independence, hence the nation and Indonesia, independent and sovereign, free from the power and influence of the power of any nation and state. National independence and the Indonesia are upheld based on the 1945 Constitution with all the dignity of the philosophical, ideological and constitutional identities and embodied in it. This means that, the nation and Indonesia uphold the philosophy of the State based on Pancasila as the order of life and culture of the nation, reflected and enforced in the order of political ideology, law, economy, social culture, and national security defense. Philosophically and normatively constitutional, the philosophy of the State based on Pancasila becomes the foundation and source of the ideals of the nation and state; enforced by the government to ensure the welfare of the people.

Citizens with special needs such as those who are blind, disabled, deaf and others, including citizens with gender issues such as the LGBT community in a human rights perspective, shall still be having equal dignity. In analogous to the citizens with special needs, the LGBT community based on human rights studies surely is included. The LGBT community in human rights study in Indonesia which is based on Pancasila will produce its own view, and due to that this research is conducted.

The research raises the legal issue regarding the LGBT Community in relation to the State based on Pancasila, seems to be apparent that the key is "State based on Pancasila". This is because, as citizens of Indonesia whose growth and development from various cultures from Sabang to Marauke, Pancasila is the unifying element of the nation, therefore Pancasila is placed as the Fundament of the State.

As a great nation, it is appropriate to know the purpose and objectives of Pancasila which then cab be projected in every aspect of life, not only in the field of law but also in the economic, social, cultural, and other fields. The purpose and objectives of Pancasila are contained in the document of the Indonesian nation, namely the history of the birth of Pancasila that embodies the whole Indonesian nation without exception.

Based on the findings of ideals and the application of the principles of national law held in 1995 as quoted by Backy Krisnayuda, ${ }^{8}$ it is agreed upon that Pancasila as the "ideal of law" (rechtsidee) which embodies the behavior of all the legal subjects of the Indonesian society, so that Indonesia can be realized upon the "Rule of Law" (rechsstaat), as emphasized in the preamble of the 1945 Constitution which states:

[...] Subsequent thereto, to form a government of the Indonesia which shall protect all the people of Indonesia and all the independence and the land that has been struggled for $[\ldots] .{ }^{9}$

Noting the substance of the fourth paragraph of the preamble of the 1945 Constitution, it can be inferred that the presence of the LGBT community it can be argued that the existence of this LGBT

Majda El Mahtaj, 2015, HAM dalam Konsitusi Indonesia, Kencana, Jakarta, p.1.

Backy Krisnayuda, 2016, Pancasila Dan Undang_undang Relasi Dan Transformasi Keduanya Dalam Sistem Ketatanegaraan Indonesia, Predana Media Group, Jakarta, p 46.

Kaelan, 2010, Pendidikan Pancasila, Paradigma, Yogyakarta, p 159 
community should be protected by the state, as after all those who are members of the LGBT community are in fact part of citizens who have equal rights and obligations as with other citizens who are born under normal circumstances. In this case Pancasila as the ideals of the nation and having hierarchy above all else is the foundation of the philosophy and ideology of the state, the view and the purpose of life of the nation, the state ideals (staatidee), and as the basis of the state, should be a benchmark and a test stone regarding the "good or bad - fairness or unfairness" of the applicable law, because Pancasila is the source above all sources of law applicable across the lands of Indonesia.

From the aspect of the system of values, Pancasila is purposed to manifest human protection, which is to passively protect humans by preventing arbitrary acts, and actively by creating a humanitarian condition that allows the process human society to grow reasonably and affording every human equal opportunity develop the full potential of their humanity. In the formulation, it also includes a goal to nurture and develop "humanity and moral ideals of the noble people based on the belief in One and Only God". Implementation of the aforementioned manifestation is carried out with the effort in realizing: ${ }^{10}$

1. Law and order that gave rise to the predictability;

2. Peace which is tranquil;

3. Justice (distributive, commutative, vindictive, protective);

4. Social welfare and justice;

5. Formation of noble character based on the Belief in the One and Only God; and

6. Participation and transparency in the public decision making process.

In the projection of Pancasila, hence its purpose and objectives must support the ideal of the national legal system that is to help the realization of social justice and people's prosperity. As mentioned in the preamble of the 1945 Constitution, stating:
1. Protect all the people of Indonesia and all the independence and the land that has been struggled for;

2. Improve public welfare;

3. Educate the life of the people; and

4. Participate toward the establishment of a world order based on freedom, perpetual peace and social justice. ${ }^{11}$

To understand the existence of the LGBT community in Indonesia, it is relevant to refer to the views of Notonagoro who opines, that the nature of Pancasila as the fundaments of the State encompasses:

First Sila, the nature of the Indonesian people towards God, determined by the nature of God, as the innate nature of God's created humans is to live in taklim and obedience to God, as the only one, as the first cause of everything and from whom everything depends on; Second Sila, the nature of the Indonesian people as an innate nature as God's creations to: fulfill their body and soul, their individual and social needs, the necessities of their religious lives; to do deeds based on the will of desire which is aimed on doing good, based on the decisions of the mind, which is aimed to facts including the truth, in harmony with the taste, which is directed to the beauty of the soul, and on the unity of the mind-feelings-the wills of faith, aimed to the absolute reality (God), and in harmony with the unity of the body, the unity as an individual human being-the social being, and the position of the very nature of the individual man (the creature of God), all of them in the balance of the harmonious-dynamic unity; Third Sila, the nature of the Indonesian people as the innate nature of the citizens of a unified Indonesia, the embodiment of the human nature as God's creature in the unity of the relationship with the fellow citizens of the country included within the unity of the relationship with fellow human beings of God's creation, is the awareness of the differences contained in the society and State, such as: Seeking the annihilation as well as the reduction of differences that could possibly result in an atmosphere and power 
of repulsion toward disputes/divisions; giving life to differences that have a pulling force toward cooperation; Willingness, competence and effort in carrying out an integral, balanced, harmonious-dynamic, organic unity and nationality of Indonesia and awareness of and by exercising the wisdom of life and the values of human life and the proper religious values; Fourth Sila, the nature of the Indonesian people as the nature of Indonesian citizens, the embodiment of the nature of God's creations which in turn manifests as the rights-obligations of human rights, within relationships with individuals, within the balance of the nature of social creatures which is to live to undergo and enjoy togetherness, independence/freedom and power over the people, the number of citizens as supporters of the power in the form of compulsory political democratic rights and as a supporter of interests in the form of a compulsory interest or functional democracy in the field of state on the basis of trinity of state, from the people, for people, and by the people in order to create the welfare and happiness of all things physical, spiritual and religious, on a trinity: one for all, all for one and all for all. Fifth Sila, the nature of the Indonesian people as an innate nature of supporters of social justice, the embodiment of the nature of humans as God's creations which in turn manifests as the rights-obligations of basic humanity, in the continuation of life with people of the same nations and fellow human beings as God's creations is to live undergoing and enjoying similarity, independence or freedom and power from individuals in balancing with the nature of humans as social creatures to undergo efforts of fulfilling interests, needs, necessities of life in physicality-spiritualityreligion which is in accordance with the characters of the human nature as God's creatures and the absolute dignity of the human person as an individual, such as: who because life is entitled to live, and in essence not because of the outcome of their efforts, but because of their right-obligation to live, in the absolute sense in accordance with the dignity of humans. ${ }^{12}$
Starting from the view of Notonagoro mentioned above, the researchers understand that the existence of the LGBT community is indeed a necessity. They have been around since time immemorial, though not openly showing themselves as lovers of the same-sex. Their existence is actually identical with the turn of time, which is marked by the rising of the sun in the east, continuing into daytime and finally towards the night. However, between the time of day and night there is a time termed as sandyakala (dusk) which is the transition period from day to night. Using an analogy of time, then the existence of this LGBT community is actually in position of sandyakala (dusk), which is not so dark into the night, but still clearly visible to be seen. The existence of the LBGT community is indeed indisputable. The LGBT community physically presents themselves like a feminine person, but biologically they actually have masculine physique, and vice versa. They are however also part of our citizens. Communities that behave like this from the point of human rights need their existence to be appreciated. As God's creations, then the LGBT community cannot be separated from human rights.

Speaking on Human Rights in Indonesia, it can be found Law of the Republic of Indonesia No. 39 of 1999 regarding Human Rights, hereinafter abbreviated as Human Rights Law. Article 1 paragraph 1 of the Human Rights Law provides the definition of human rights as follows:

A set of rights bestowed by God Almighty in the essence and being of humans as creations of God which must be respected, held in the highest esteem and protected by the state, law, Government, and all people in order to protect human dignity and worth. Human obligations mean a set of obligations which, if not undertaken, would make it impossible for human rights to be executed and upheld. ${ }^{13}$

In these past few decades, Human Rights is one of the phrases most frequently discussed

2 Notonagoro, 1974, Pancasila Dasar Filsafat Negara Republik Indonesia, Pantjuran Tudjuh, Jakarta, p. 49.

13 Article 1 Paragraph 1 Law Number 39 of 1999 on Energy (State Gazette of the Republic of Indonesia Year 2007 Number 96, Supplement to 
upon regarding the legal issues in Indonesia. Unfortunately, often the said phrase is not used in the proper context, leading to the blurring of its true meaning. In Indonesia there is a tendency for failure to investigate or prosecute matters concerning human rights ranging from Munir case, LP Cebongan case, and to cases involving the LGBT community. Human Rights is a right earned from the moment of birth without distinction on the basis of nation, race, religion, sex etc.

The definition of Human Rights according to John Locke, is a set of rights attached to the nature and existence of human beings as creatures of God Almighty and is His grace that must be respected, upheld and protected by the state, law, government and everyone, for the honor and protection of human dignity (article 1 paragraph 1 of the Human Rights Law and Law No. 26 of 2000 regarding Human Rights Court). ${ }^{14}$

Based on Article 4 of Human Rights Law it is stated a number of human rights that are absolute in nature, which cannot be derogated from under whatever condition or by anyone whosoever. The rights mentioned above are as follows: ${ }^{15}$

1. Right to life;

2. Right to not be tortured;

3. Right to freedom of the individual, to freedom of thought and conscience;

4. Right to practice religion;

5. Right to not be enslaved;

6. Right to be acknowledged as an individual before the law;

7. Right not to be prosecuted retroactively under the law.

The formulation of Article 4 of the Human Rights Law is in line with the formulation of Article 28 I paragraph (1) of the Amended 1945 Constitution which stipulates:

The rights to life, freedom from torture, freedom of thought and conscience, freedom of religion, freedom from enslavement, recognition as a person before the law, and the right not to be tried under a law with retrospective effect are all human rights that cannot be limited under any circumstances." The sentence "cannot be limited under any circumstances" denotes that the rights mentioned are absolute rights, which cannot be limited, even if in Article $28 \mathrm{~J}$ paragraph (2) of the 1945 Constitution it is established an obligation to respect the rights and freedom of other people within the restrictions established by law.

Where such right is an absolute right, and when it is associated with the existence of the LGBT community, recognition as a person and equal treatment and protection before the law creates the right as a person to demand the government to fulfill and provide equal protection and treatment before the law (see article 5 and article 8 of the Human Rights Law).

International recognition towards Human Rights protection which is embedded within the consideration of the Universal Declaration also mentions several special rights which must be protected as expressions of the right to life and freedom, namely freedom of speech, freedom of religion and freedom from fear. The existence of the LGBT community is still haunted by fear. In order to create something more binding than a mere declaration, the United Nations Human Rights Commission establishes two covenants and a protocol that is part of the four United Nations products called the International Bill of Human Rights, which consists of:

1. Universal Declaration;

2. The International Covenant on Economic, Social and Cultural Rights (ICESR);

3. The International Covenant on Civil and political Rights (ICCPR);

4. Optional Protocol to the International Covenant on Civil and Political Rights.

Martin Luther King Jr. (1929-1968), well

State Gazette of the Republic of Indonesia Number 4746)

14 John Locke in O.C.Kaligis, 2013, HAM \& Peradilan HAM, Yarsif Watampone, Jakarta, p.14.

15 Article 4 Law Number 39 of 1999 on Energy (State Gazette of the Republic of Indonesia Year 2007 Number 96, Supplement to State Gazette of the Republic of Indonesia Number 4746). 
known as "an American black leader" and the 1964 Noble Prize Laureate, once opined: "Law and order exist for the purpose of establishing justice and when they fail in this purpose they become the dangerously structured dams that block the flow of social progress." ${ }^{\prime 16}$ Protection against fundamental freedom is necessary for human existence as a social being and a condition for justice. The purpose of the existence of laws and regulations is to uphold justice. Failure to achieve this goal makes laws and regulations a dangerous dam that blocks the flow of social development. This means that the Criminal Justice System as an integral part of the law must reflect the purpose of the existence of the law, namely the establishment of justice. Universally, the world community recognizes that every human being has a number of rights that belong to them since their existence as a human is recognized, even though the human has not been born into this world. ${ }^{17}$

The definition of Human Rights according to Jan Martenson is those rights which are inherent in our nature and without which we cannot live as human being. Initially, the above understanding is universally accepted, but in its development and more specifically, in its implementation into a positive legal system, the theories and concepts of Human Rights have been debated and controversy between one nation and another.

The controversy arose because at the outset it was difficult to establish the real and definitive limits of human rights. These rights revolve around the notion of freedom and the principle of equality. Principles will always be the arena of differences in understandings and differing theories. Consequently, the notion and limits of human rights became relative and influenced by schools of thought, religion and customs, conditions and situations. ${ }^{18}$

With regards to the legal issues that is currently being researched is the existence of the
LGBT community in the perspective of a State based on Pancasila, hence whether the existence of LGBT behavior has been in contrary with Human Rights. Based on the results of the research by taking data directly through interviews with LGBT groups, it is clear that the LGBT are actually no different from citizens in general, who have the right to be treated equally and not discriminatively.

The easiest example is the right to life as a human right. The right to life has been guaranteed in various international and national instruments as one of the most basic right. The LGBT community in a nation based on the Rule of Law such as Indonesia, its existence still has not received maximum recognition in accordance with our constitution. For example, to establish a family through samesex marriage, is not possible in a State based on Pancasila; due to the fact that the Marriage Law is limitative through the provisions of Article 1 has provided that the marriage is a mental bond between a man and a woman as husband and wife in order to form a happy and eternal household (family) based on God Almighty. Similarly, in Article 3, paragraph (1) of the Marriage Law, it has been made clear that in principle within a marriage a man may only have one wife. A woman may only have one husband. Hence, starting from the provisions of Article 1 and Article 3 paragraph (1) of the Marriage Law, it is clear that the State does not give an opportunity to the LGBT community to undergo same-sex marriage. The existence of the LGBT community from a human rights perspective has indeed gained recognition, except in the case of marriage, even if marriage is a right. However, the State has not provided an opportunity for marriage for same-sex couples.

Based on the results of direct observation in the field at their place of daily activities, we can conclude the fact that the LGBT community in their daily life does nothing wrong in terms of law. Based on the admission of those determining themselves

\footnotetext{
${ }^{6}$ Martin Luther King Jr in O.C Kaligis, Ibid., p.17.

O.C.Kaligis, 2006, Perlindungan Hukum Atas Hak Asasi Tersangka, Terdakwa dan Terpidana, PT.Alumni, Jakarta, p. 49.

18 Ibid.
} 
as lesbian, as expressed by Jovania whose biological sex is female but for the needs of sexuality is more dominant thus utilizing male hormones, making them uninterested in relationships with men, thus in their daily life conduct sexual relationships with fellow females. Their relationship with their girlfriends is like those who are born as normal human beings according to their gender. Those who are gay tend to portray feminine behavior, however at times these couples alternate their positions in the relationship, sometimes wanting to be the woman, and sometimes wanting to be the man. Their sexual desires tend to lean towards "males are okay" and "females are okay too". Such behavior makes these gays tend toward bisexuality.

Observing to the behavioral habits of this community, judging from the formal legal aspect, there is no wrongdoing; as long as they are normatively do not conduct unlawful acts. Based on the results of direct interviews to the sources who are members of the LGBT community, all of them want to be treated just like those with normal personalities according to their biological sex. For example, deep within their hearts they all have the desire for same-sex marriage. However, they realize that in Indonesia the law has not allowed them to realize their desire to marry, hence their relationship cannot be publicly displayed.

\section{Alternative Solutions Towards The Presence of LGBT}

The LGBT community in Indonesia in actuality is a non-separable part of being an Indonesian citizen. They have rights and positions equal to those of other citizens. This is in line with Law No. 39 of 1999 regarding Human Rights (Human Rights Law). Within the provisions of Article 1 paragraph (1) it is stipulated that Human Rights is a set of rights bestowed by God Almighty in the essence and being of humans as creations of God which must be respected, held in the highest esteem and protected by the state, law, Government, and all people in order to protect human dignity and worth. Based on the definition of human rights, the ownership of rights of the LGBT community cannot be separated with human rights itself. Human rights are indeed rights given by God Almighty that is almost known by all religions in the world.

Treating the LGBT discriminatively will severely be in contrary to the main purpose of the law which is to afford justice. Is our State not a State based on the law? Therefore, the law must be closely intertwined with justice. This is in line with Abdul Ghofur Anshori's view which states that the law is a just law, should a concrete regulation that is a law be in contrary to the principles of justice, and then the law is no longer normative, and cannot be regarded as law. Regulations only become law when it fulfills the principles of justice. That is, fairness is a constitutive element of all understanding of the law. ${ }^{19}$

The LGBT community should not be generalized as those conducting deviant acts, as there are those among them who have the potential to be optimized as part of the State's citizens who bear equal responsibility to the nation and the State. This equality before the law is a principle where every person is subjected to the law. Therefore, the LGBT community must be treated similarly to treatments of other citizens who are deemed normal. The Constitutional Court has also rejected the criminalization of LGBT and extramarital relations according to Decision No 46/PUU-XIV/2016. Those who are guilty should be subjected to punishment, regardless of whether they belong to the LGBT community or a normal person. The implication is that should the LGBT communities violate legal norms and religious norms they then should be punished according to their crime.

In order for the existence of the LGBT community not to have a negative impact on the association of the nation's generation, they should be equipped with a deep understanding on the norms of law and religious norms. Considering 
that, based on the results of research that the authors have conducted, most of those belonging to the LGBT community wish to be treated equally as other citizens who are free from discriminatory treatments in terms of economic, legal and social treatments.

The existence of those classified as LGBT are still seen as deviant behavior by some people, especially seeing their willingness to same-sex marriage, and receive equal treatment in forming a family. Due to this fact, then besides needing to be given thorough understanding of law and norms of religion, it is also vital that they are given understanding about danger of same-sex relationships or deviant sex behavior. This is due to the fact that after all same-sex relationships will have a negative impact on the younger generation of the nation.

\section{Conclusion}

Based on the results and discussion above, there are three things that can be concluded, first, the existence of the LGBT community in the Pancasila State is in fact inevitable, as this community is part of the citizens of the state who are not different from other citizens, having the same rights and obligations towards the nation and the State. Second, Treating them discriminatively in terms of economy, law or politics is in fact a violation towards Human Rights. Third, The alternative solution which can be undertaken to prevent negative implications from the activities of the LGBT community is through an increase in the understanding of norms of law and norms of religion. Only through the increase of awareness of the law itself, and the understanding of religious values that those within the LGBT community can avoid conducting acts that violate the law and religious norms.

\section{REFERENCES}

\section{A. Books}

Anshori, Abdul Ghofur, 2010, Filsafat Hukum Kewarisan Islam:Konsep Kewarisan Bilateral Hazairin, UII Press, Yogyakarta.

Departemen Pendidikan Nasional, 2010, Kamus Besar Bahasa Indonesia, Departemen Pendidikan Nasional, Jakarta.

Fletcher, Geor P., 1996, Basic Concepts of Legal Thought, Oxford University Press.

Kaelan, 2010, Pendidikan Pancasila, Paradigma, Yogyakarta

Kaligis, O.C., 2006, Perlindungan Hukum Atas Hak Asasi Tersangka, Terdakwa dan Terpidana, PT.Alumni, Jakarta. , 2013, HAM \& Peradilan

HAM, Yarsif Watampone, Jakarta.

Krisnayuda, Backy, 2016, Pancasila Dan Undang undang Relasi Dan Transformasi Keduanya Dalam Sistem Ketatanegaraan Indonesia, Predana Media Group, Jakarta.

Mahtaj, Majda El, 2015, HAM Dalam Konsitusi
Indonesia, Kencana, Jakarta.

Notonagoro, 1974, Pancasila Dasar Filsafat Negara Republik Indonesia, Pantjuran Tudjuh, Jakarta.

Palguna, I Dewa Gede, 2013, Pengaduan Konstitusional (constitutional Complaint) Upaya Hukum Terhadap Pelanggaran HakHak Konstitusional Warga Negara, Sinar Grafika, Jakarta.

Syam, Mohamad Noor, 1998, Penyebaran Filsafat Pancasila Dalam Filsafat Hukum, Lab. Pancasila IKIP Malang, Malang.

\section{B. Government Regulations}

Law Number 39 of 1999 on Energy (State Gazette of the Republic of Indonesia Year 2007 Number 96, Supplement to State Gazette of the Republic of Indonesia Number 4746). 